
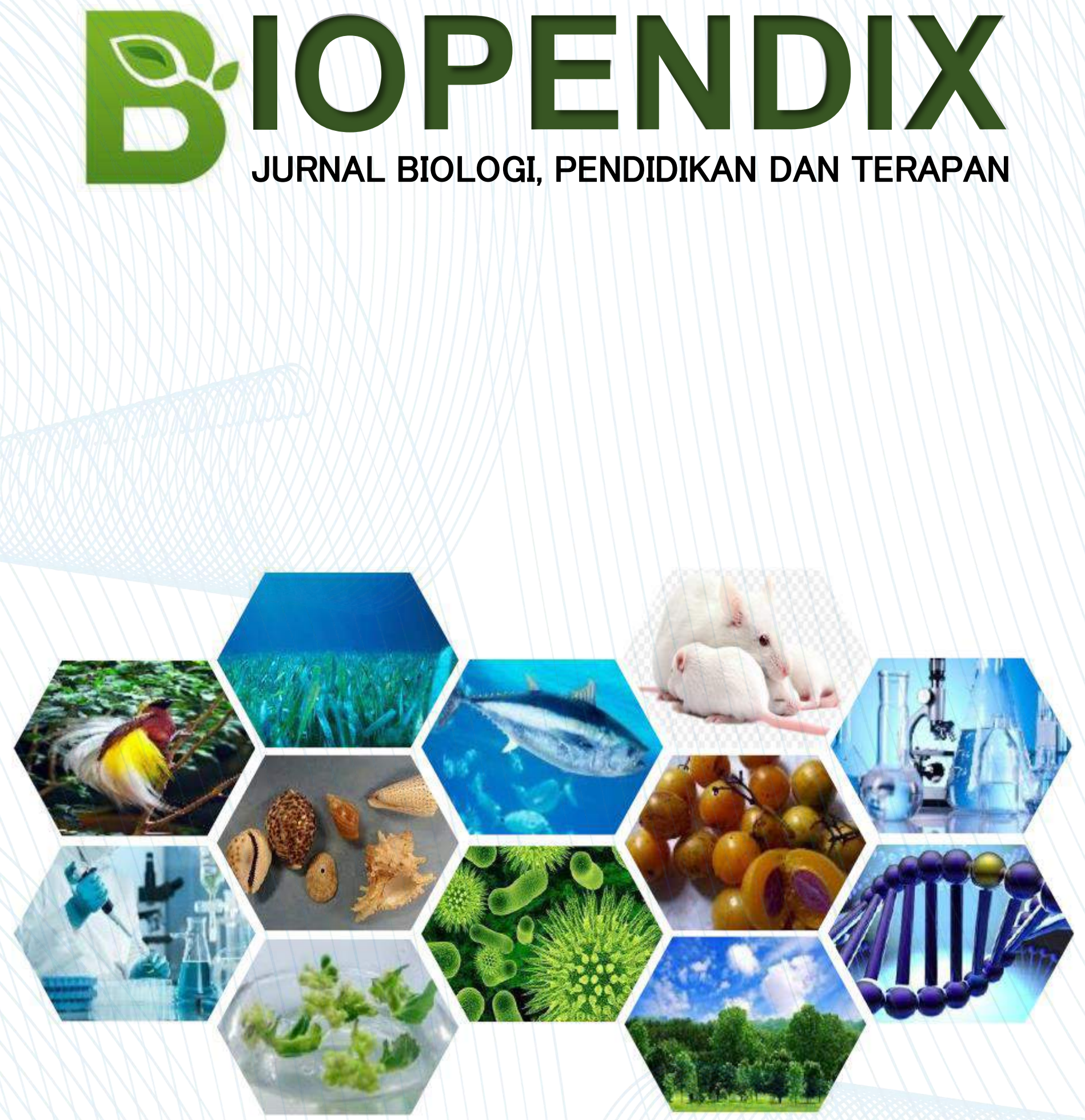

PUBLISHER BY:

BIOLOGY EDUCATION, UNPATTI AMBON - MALUKU 


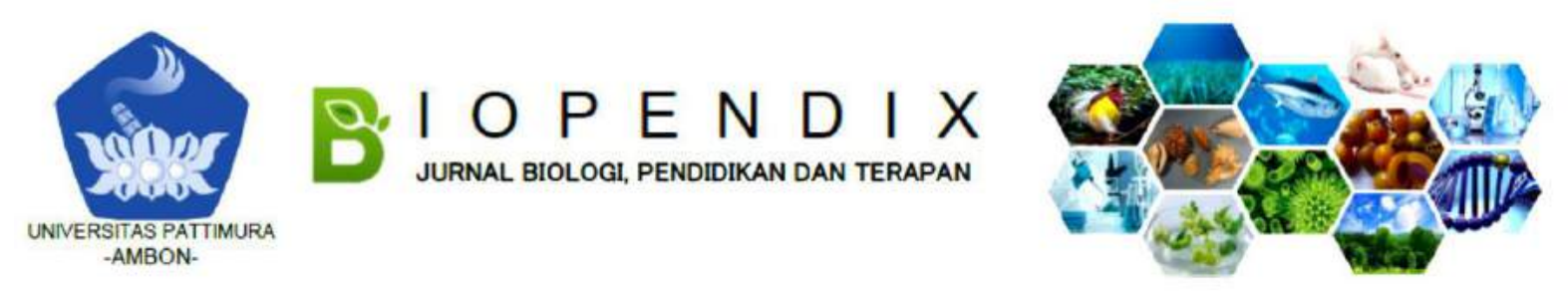

\title{
PENERAPAN PERANGKAT PEMBELAJARAN \\ MODEL QUANTUM LEARNING TERHADAP HASIL BELAJAR SISWA KELAS X SMA KARTIKA XIII-1 AMBON
}

\author{
Adhar Amir ${ }^{1}$, S.I.A Salmanu*2, Ine Arini² \\ ${ }^{1}$ Alumni Program Studi Pendidikan Biologi; ${ }^{2}$ Program Studi Pendidikan Biologi \\ *Corresponding author: S.I.A Salmanu; e-mail: siasalmanu.unpatti@gmail.com
}

\begin{abstract}
Background: Quantum learning model is a set of learning models that are proven to be effectively applied in schools. This study aims to determine the application of biological learning devices using quantum learning models to the learning outcomes of virus material can improve student learning outcomes in class X SMA Kartika XIII-1 Ambon.

Method: This type of research is descriptive type. The population in this study is SMA Kartika XIII-1 Ambon. The samples in this study were all students of class X MIA SMA Kartika XIII-1 Ambon, amounting to 16 students. The data obtained were analyzed descriptively and inferentially.

Results: In the cognitive aspect of 16 students there were 5 students with a percentage (31.25\%) getting grades (85-100) with very good qualifications and 11 students with a percentage $(68.75 \%)$ getting grades (77-84) with qualifications well. Affective aspects, where at intervals of 77-84 there are 13 students $(81.25 \%), 3$ students score at intervals of $70-76(18.75 \%)$ who have this value with complete qualifications. Psychomotor aspects, where at intervals of $\geq 70$ there are 16 students $(100 \%)$ who have grades with complete qualifications.

Conclusion: The level of student success viewed from cognitive, affective, and psychomotor aspects. This is in accordance with the analysis data and the percentage data obtained at the initial test was $65.31 \%$ while the final percentage of the test produced was $79.68 \%$.
\end{abstract}

Keywords: Quantum Learning, learning outcomes, viruses

\begin{abstract}
Abstrak
Latar Belakang: Model pembelajaran Quantum learning adalah seperangkat model belajar yang terbukti efektif diterapkan di sekolah. Penelitian ini bertujuan untuk mengetahui penerapan perangkat pembelajaran biologi dengan menggunakan model quantum learning terhadap hasil belajar materi virus dapat meningkatkan hasil belajar siswa kelas X SMA Kartika XIII-1 Ambon.

Metode: Tipe penelitian ini adalah tipe deskriptif. Populasi dalam penelitian ini adalah SMA Kartika XIII1 Ambon. Sampel dalam penelitian ini seluruh siswa kelas X MIA SMA Kartika XIII-1 Ambon yang berjumlah 16 orang siswa. Data yang diperoleh dianalisis secara deskriptif dan inferensial.

Hasil: Pada aspek kognitif dari 16 siswa terdapat 5 siswa dengan presentase $(31,25 \%)$ memperoleh nilai (85-100) dengan kualifikasi sangat baik dan 11 siswa dengan presentase $(68,75 \%)$ memperoleh nilai (77-84) dengan kualifikasi baik. Aspek afektif, dimana pada interval 77-84 terdapat 13 siswa (81,25\%), 3 siswa nilai pada interval $70-76(18,75 \%)$ yang memiliki nilai ini dengan kualifikasi tuntas. Aspek psikomotor, dimana pada interval $\geq 70$ terdapat 16 siswa $(100 \%)$ yang memiliki nilai dengan kualifikasi tuntas.

Kesimpulan: Tingkat keberhasilan siswa yang dilihat dari aspek kognitif, afektif, dan psikomotor. Hal ini sesuai dengan data analisis dan data presentase yang diperoleh pada tes awal adalah $65,31 \%$ sedangkan tes akhir presentase yang di hasilkan mencapai $79,68 \%$.
\end{abstract}

Kata Kunci: Quantum Learning, hasil belajar, virus 


\section{PENDAHULUAN}

Keberhasilan pendidikan didukung oleh berbagai hal, diantaranya pengembangan sistem pendidikan. Pengembangan yang dimaksud merupakan proses meningkatnya mutu layanan pendidikan, peningkatan sarana dan prasarana pendidikan, serta pengayaan metode dan media pembelajaran. Mahmud (2011) menjelaskan bahwa melalui pengembangan sistem pembelajaran, maka profesionalitas pendidik yang mampu harus diupayakan, karena pendidik merupakan aset utama dalam pendidikan.

Profesionalitas pendidik dibuktikan melalui inovasi dalam pembelajarannya. Salah satu inovasi yang dapat ditunjukkan adalah melalui pengembangan perangkat pembelajaran kontekstual yang mampu memotivasi dan menjangkau akademik siswa baik akademik tinggi, sedang maupun rendah. Proses pengembangan perangkat pembelajaran yang kontekstual tentunya bersumber dari model, strategi dan metode pembelajaran yang dipilih guru untuk dikembangkan bersama dengan materi yang sulit dikuasai oleh siswa.

Model pembelajaran quantum learning merupakan salah satu model atau falsafah belajar yang telah terbukti efektif diterapkan di sekolah. Istilah lain yang hampir dapat dipertukarkan dengan suggestology adalah pemercepatan belajar" (accelerated learning). Percepatan belajar didefenisikan sebagai "memungkinkan siswa untuk belajar dengan kecepatan yang mengesankan, dengan upaya yang normal, dan dibarengi kegembiraan" (De Porter dan Hernacki, 2007). Menerapkan model quantum learning mencakup petunjuk spesifik untuk menciptakan lingkungan belajar yang efektif, menyampaikan proses pembelajaran, dan memudahkan proses belajar. Melalui penerapan model quantum learning ini diharapkan dapat meningkatkan hasil belajar siswa Hasil belajar adalah perubahan perilaku siswa akibat belajar. Perubahan perilaku disebabkan karena mencapai penguasaan atas sejumlah bahan yang diberikan dalam proses belajar mengajar. Pencapaian itu didasarkan atas tujuan pengajaran yang telah ditetapkan. Hasil itu dapat berupa perubahan dalam aspek kognitif, afektif maupun psikomotor (Purwanto, 2011).
Berdasarkan survei yang dilaksanakan di SMA Kartika XIII-1 Ambon diketahui bahwa materi yang sulit dihadapi oleh siswa adalah virus. Pembelajaran yang efektif dengan suasana belajar yang menyenangkan dapat mendukung pola pikir siswa untuk menemukan permasalahan yang terjadi pada proses pembelajaran, sehingga dengan hal tersebut siswa mampu mendapatkan hasil belajar yang baik.

Tujuan dari penelitian ini adalah untuk mengetahui penerapan perangkat pembelajaran biologi dengan menggunakan model quantum learning terhadap hasil belajar pada materi virus dapat meningkatkan hasil belajar siswa kelas $X$ Mia SMA Kartika XIII-1 Ambon.

\section{METODE}

Penelitian ini merupakan tipe penelitian deskriptif untuk mengetahui hasil belajar siswa pada materi virus yang diajarkan menggunakan model quantum learning terhadap siswa kelas X MIA SMA Kartika XIII-1 Ambon. Populasi dalam penelitian ini adalah SMA Kartika XIII-1 Ambon. Sampel dalam penelitian ini seluruh siswa kelas $X$ MIA SMA Kartika XIII-1 Ambon yang berjumlah 16 orang siswa. Pengumpulan data dalam penelitian ini untuk memperoleh data hasil belajar dilakukan dengan cara tes dengan soal essay. Data yang di dapat dalam penelitian ini akan di analisis secara deskriptif dan inferensial. Nilai hasil belajar siswa akan menggunakan rumus sebagai berikut:

Hasil belajar $=\frac{\text { Nilai yang di peroleh siswa }}{\text { Total nilai }} \times 100$

Nilai akhir ditentukan dengan rumus:

$$
\mathrm{NA}=\frac{6 \mathrm{P}+4 \mathrm{~F}}{10}
$$

Keterangan:

NA : Nilai Akhir

$P \quad$ : Nilai proses yang di peroleh dari nilai kognitif LKS, afektif dan psikomotor.

F : Nilai formatif setelah proses pembelajaran. 


\section{HASIL DAN PEMBAHASAN}

\section{a. Hasil}

Berdasarkan hasil penelitian penerapan perangkat pembelajaran biologi dengan menggunakan model quantum learning terhadap hasil belajar siswa sudah baik,

Untuk mengetahui hasil belajar siswa pada mata pelajaran Biologi pada materi virus di SMA Kartika XIII-1 Ambon, penulis memperoleh data hasil belajar dari hasil pre test dan post test yang di berikan kepada 16 siswa yang di jadikan sebagai sampel dalam penelitian. Hasil dari pre test dan post test tersebut akan memberikan gambar peningkatan hasil belajar siswa. Hasil belajar siswa sebelum pembelajaran (pretest) dengan menggunakan penerapan model Quantum Learning.

Kemampuan awal siswa sebelum mengikuti kegiatan belajar mengajar (KBM) materi virus dengan penerapan model Quantum Learning yang digambarkan dalam hasil pretest menunjukkan bahwa pencapaian siswa pada pretest ini rendah atau dapat di kategorikan gagal. Hal tersebut di gambarkan pada tabel berikut.

Tabel 1. Kualifikasi Tingkat Penguasaan Siswa Pada Tes Awal (Pre Test)

\begin{tabular}{cccc}
\hline Interval & Frekuensi & $\%$ & Kualifikasi \\
\hline $85-100$ & 1 & $6,25 \%$ & $\begin{array}{c}\text { Sangat } \\
\text { baik }\end{array}$ \\
& & & Baik \\
$77-84$ & 1 & $6,25 \%$ & Cukup \\
$70-76$ & 4 & $25 \%$ & Kurang \\
$50-69$ & 9 & $56,25 \%$ & Gagal \\
$\leq 49$ & 1 & $6,25 \%$ & Gaga \\
Jumlah & 16 & 100 & \\
\hline
\end{tabular}

Dari tabel terlihat hasil pada tes awal siswa belum tuntas belajar. Hal ini terbukti dengan 14 siswa belum mencapai kriteria ketuntasan minimal (KKM).

Hasil belajar siswa dalam kegiatan proses belajar mengajar dengan menerapkan perangkat pembelajaran Biologi menggunakan model Quantum Learning dinilai berdasarkan 3 aspek yaitu aspek kognitif, aspek afektif dan aspek psikomotor. Penilaian aspek kognitif dilakukan melalui lembar kerja siswa (LKS) sedangkan pada aspek afektif dan psikomotor merupakan penilaian menggunakan lembar observasi yang disediakan oleh peneliti.
Berdasarkan hasil penelitian yang di lakukan pada SMA Kartika XIII-1 Ambon, kemampuan kognitif siswa dalam proses pembelajaran dalam hal ini siswa mengerjakan lembaran kerja siswa (LKS) yang digunakan untuk melihat hasil kerja siswa di kelas. Hasilnya digambarkan pada tabel berikut.

\section{Tabel 2. Kualifikasi Penilaian Rata-Rata Hasil Kognitif}

\begin{tabular}{|c|c|c|c|}
\hline Interval & Frekuensi & $\%$ & Kualifikasi \\
\hline $85-100$ & 5 & $31.25 \%$ & $\begin{array}{l}\text { Sangat } \\
\text { baik }\end{array}$ \\
\hline $77-84$ & 11 & $68.75 \%$ & Baik \\
\hline $70-76$ & - & . & Cukup \\
\hline $50-69$ & - & - & Kurang \\
\hline $\begin{array}{c}\leq 49 \\
\text { Jumlah }\end{array}$ & - & - & Gagal \\
\hline
\end{tabular}

Berdasarkan tabel 2 diatas dapat diketahui bahwa dari 16 siswa terdapat 5 siswa dengan presentase $(31,25 \%)$ memperoleh nilai (85-100) dengan kualifikasi sangat baik,dan 11 siswa dengan presentase $(68,75 \%)$ memperoleh nilai $(77$ 84) dengan kualifikasi baik.

Data mengenai kemampuan afektif siswa diperoleh selama proses pembelajaran dengan menerapkan model pembelajaran Quantum learning ditunjukkan pada nilai unjuk kerja selama proses pembelajaran. Kualifikasi rata-rata skor pencapaian siswa pada aspek afektif dapat dilihat pada tabel berikut.

\section{Tabel 3. Hasil Penilaian Afektif}

\begin{tabular}{|c|c|c|c|}
\hline Interval & Frekuensi & $\%$ & Kualifikasi \\
\hline $85-100$ & - & - & $\begin{array}{c}\text { Sangat } \\
\text { baik }\end{array}$ \\
\hline $77-84$ & 13 & $81.25 \%$ & Baik \\
\hline $70-76$ & 3 & $18.75 \%$ & Cukup \\
\hline $50-69$ & - & . & Kurang \\
\hline $\begin{array}{c}\leq 49 \\
\text { Jumlah }\end{array}$ & - & - & Gagal \\
\hline
\end{tabular}

Berdasarkan data pada tabel hasil penilaian afektif dapat dilihat bahwa 13 siswa dengan presentase $81.25 \%$ memperoleh nilai (77-84) yang berada pada kualifikasi baik, dan ada 3 siswa dengan presentase $18.75 \%$ yang berada pada kualifikasi cukup. 
Data dari penilaian aspek psikomotor diperoleh melalui lembar observasi yang digunakan untuk menilai kemampuan siswa yang meliputi: Menggunakan sumber belajar, menentukan pertanyaan, mempresentasikan hasil diskusi, dan kerja sama. Hasilnya dapat dilihat pada tabel berikut.

\section{Tabel 4. Hasil Penilaian Psikomotor}

\begin{tabular}{cccc}
\hline Interval & Frekuensi & $\%$ & Kualifikasi \\
\hline $85-100$ & 2 & $12.5 \%$ & $\begin{array}{c}\text { Sangat } \\
\text { baik }\end{array}$ \\
& & & Baik \\
$77-84$ & 12 & $75 \%$ & Cukup \\
$70-76$ & 2 & $12,5 \%$ & Kurang \\
$50-69$ & - & - & Gagal \\
$\leq 49$ & - & - & \\
Jumlah & & & \\
\hline
\end{tabular}

Pada tabel diatas menunjukkan bahwa data yang diperoleh dari penilaian psikomotor terdapat 2 siswa dengan presentase $12,5 \%$ memperoleh nilai interval (85-100) yang berada pada kualifikasi sangat baik,dan 12 siswa dengan presentase $75 \%$ memperooleh nilai interval (77-84) yang berada pada kualifikasi baik. 2 siswa lainnya dengan preesentase 12,5\% memperoleh nilai interval (70-76) yang berada pada kualifikasi cukup.

Posttest di laksanakan setelah proses pembelajaran dengan penerapan model Quantum Learning. Hasil belajar pada tes akhir merupakan hasil belajar siswa setelah di terapkan model Quantum Learning. Hasilnya dapat dilihat pada tabel berikut.

Tabel 5. Kualifikasi Hasil Tes Akhir

\begin{tabular}{cccc}
\hline Interval & Frekuensi & $\%$ & Kualifikasi \\
\hline $85-100$ & 6 & $37.5 \%$ & $\begin{array}{c}\text { Sangat } \\
\text { baik }\end{array}$ \\
& & & Baik \\
$77-84$ & 4 & $25 \%$ & Cukup \\
$70-76$ & 6 & $37.5 \%$ & Kurang \\
$50-69$ & - & - & Gagal \\
$\leq 49$ & - & - & \\
Jumlah & & & \\
\hline
\end{tabular}

Dari tabel di atas dapat dilihat bahwa 6 siswa dengan presentase $37,5 \%$ mampu menguasai indikator pembelajaran dengan kualifikasi sangat baik sedangkan 4 siswa dengan presentase $25 \%$ mendapat kualifikasi baik, dan 6 siswa dengan presentase $37.5 \%$ mendapat kualifikasi kurang. Hal ini membuktikan bahwa setelah proses belajar mengajar dilakukan dengan model pembelajaran quantum learning berbasis metakognitif dengan konsep materi virus menjadi lebih baik dari pada sebelumnya saat tes awal dan nilainya mencapai standar KKM.

\section{b. Pembahasan}

Hasil Belajar

1) Tes awal

Hasil belajar adalah peningkatan mengenai berbagai pengetahuan, kemampuan, kebiasaan, dan ketrampilan siswa setelah melakukan proses belajar mengajar (Lufri, 2010).

Sardiman (2005) mengemukakan bahwa setiap proses belajar-mengajar akan diperoleh suatu hasil yang disebut hasil pengajaran atau hasil belajar.

Sebelum peneliti melakukan penelitian dengan menerapkan model Quantum Learning, secara tidak terstruktur peneliti telah melakukan observasi berupa mewawancarai guru mata pelajaran Biologi di kelas X MIA-1 SMA Kartika XIII-1 Ambon. Wawancara tersebut di maksud untuk mengetahui gambaran tentang kemampuan siswa pada kelas yang di jadikan sampel dan untuk mengetahui sejauh mana kemampuan atau kompetensi yang di milki siswa tentang materi virus yang akan di ajarkan, maka peneliti memberikan tes awal sebelum proses pembelajaran berlangsung.

Berdasarkan hasil tes awal yang di peroleh menggambarkan kemampuan hasil belajar siswa sebelum proses pembelajaran, terlihat bahwa tingkat penguasaan siswa kelas X MIA-1 SMA Kartika XIII-1 Ambon terhadap indikator pembelajaran pada materi virus tergolong rendah, di lihat dari rata-rata skor pencapaian untuk kemampuan awal siswa maka, kemampuan awal yang dimiliki oleh siswa (16 orang) hanya 2 orang siswa yang mencapai kriteria ketuntasan minimal (KKM) dan 14 siswa lainnya belum mencapai kriteria ketuntasan minimal (KKM).

Rendahnya kemampuan awal siswa, disebabkan karena tidak ada kesiapan belajar dari siswa dan model pembelajaran yang digunakan terkesan monoton. Kenyataan tersebut, mengharuskan guru menerapkan pembelajaran yang menjadikan 
siswa aktif dan terlibat dalam proses pembelajaran guna mencapai indikator pembelajaran. Kemampuan awal memegang peranan yang sangat penting, karena apa yang telah dimiliki siswa akan berpengaruh terhadap apa yang akan mereka pelajari untuk mempermudah siswa dalam proses-proses internal dalam diri siswa ketika belajar.

\section{2) Hasil Belajar Siswa Yang Diajarkan Dengan Model Pembelajaran Quantum Learning}

Berdasarkan langkah-langkah model pembelajaran quantum learning yang dikenal dengan sebutan TANDUR (De Porter \& Hernacki, 2007) yang diterapkan untuk siswa. Saragih dan Kristiani (2007) menjelaskan bahwa pada tahapan ini guru memberikan siswa kesempatan untuk mendemonstrasikan dan mempraktekan materi yang baru mereka pelajari.

Adityarini, dkk (2013) melaporkan penelitiannya bahwa ada peningkatan hasil belajar aspek kognitif pada materi animalia melalui penerapan model pembelajaran Quantum Learning dengan bantuan media Flashcard maka terjadi peningkatan sebesar $2,8 \%$ yaitu dari $77,24 \%$ pada siklus I menjadi $80,05 \%$ di siklus II.

Siswa dibagi dalam 3 kelompok, data diperoleh dari penilaian aspek kognitif diambil secara individu sekalipun pengerjaan dalam bentuk kelompok dan terbukti bahwa hasil yang di dapat menunjukkan bahwa siswa mampu untuk mengerjakan dan menyelesaikan setiap soal yang terdapat dalam LKS pada proses pembelajaran. Safryadi, dkk (2013), menyatakan bahwa belajar kognitif melibatkan tiga proses yang berlangsung hampir bersamaan yaitu memperoleh informasi baru, transformasi informasi dan menguji relevansi dan ketepatan

Penilaian selama proses pembelajaran, tidak dapat lepas dari penilaian terhadap ranah afektif. Hal senada juga disampaikan oleh Sukanti (2010) bahwa ranah afektif harus nampak dalam proses dan hasil belajar yang dicapai peserta didik oleh karena itu harus dinilai hasil-hasilnya. Aspek afektif merupakan aspek yang berkaitan dengan sikap dan nilai. Tujuan dari penilaian afektif, yaitu untuk melihat sikap dan perilaku siswa bukan pengetahuan saja. Tabel 2 terlihat hasil pencapaian siswa pada aspek afektif, dimana pada interval 77-84 terdapat 13 siswa $(81,25 \%), 3$ siswa nilai pada interval $70-76(18,75 \%)$ yang memiliki nilai ini dengan kualifikasi tuntas. Hasil ini membuktikan bahwa dalam proses pembelajaran siswa mampu merespon dengan baik proses pembelajaran yang berlangsung. Pada aspek afektif yang dinilai adalah sistematis, responsif terhadap keputusan guru, menunjukkan pemahaman, dan ketepatan menamai virus.

Kemampuan psikomotorik melibatkan gerak adaptif (adaptive movement) atau gerak terlatih dan keterampilan komunikasi berkesinambungan (non-discursive communication) (Depdiknas, 2008). Aspek psikomotor dinilai melalui lembar observasi dan skor perolehan hasil, kemampuan psikomotor selama proses pembelajaran telah tersaji dalam tabel 4 terlihat hasil pencapaian siswa pada aspek psikomotor, dimana pada interval $\geq 70$ terdapat 16 siswa $(100 \%)$ yang memiliki nilai dengan kualifikasi tuntas. Pada aspek psikomotor yang dinilai adalah kerjasama, proaktif, alasan logis/masuk akal, menggunakan kalimat sendiri.

Setelah melakukan proses belajar mengajar (PBM) dengan menerapkan model pembelajaran quantum learning dalam pembelajaran Biologi pada pertemuan I dan II sebanyak 0 siswa (0\%) mendapatkan nilai di bawah KKM, sedangkan siswa yang mendapatkan nilai memenuhi KKM adalah 16 orang siswa (100\%), maka dapat dilihat bahwa ada peningkatan jumlah siswa yang mendapatkan nilai $\geq 70$ (nilai diatas KKM) dalam mata pelajaran Biologi langkahlangkah model pembelajaran Quantum learning mengarahkan siswa pada percepatan dalam proses pembelajaran dan kerja sama, kebebasan menyampaikan pendapat, dan bertanggung jawab pada kelompok dan diri sendiri dalam menyelesaikan suatu masalah. Hasil belajar psikomotor sebenarnya tahap lanjutan dari hasil belajar afektif yang baru nampak dalam kecenderungan-kecenderungan untuk berperilaku (Sudjana, 2010).

\section{3) Nilai Akhir (NA)}

Berdasarkan hasil yang diperoleh, maka dapat dikatakan bahwa penerapan pembelajaran biologi meggunakan model 
Quantum Learning dapat membantu dalam meningkatkan hasil belajar IPA Biologi konsep virus kelas X MIA-1 SMA Kartika XIII1 Ambon. Hal ini disebabkan karena pembelajaran ini memiliki kelebihan, yaitu :

a. Quantum learning lebih bersifat humanistis.

b. Quantum learning memusatkan perhatian pada interaksi yang bermutu dan bermakna, bukan sekadar transaksi makna.

c. Quantum learning sangat menekankan pada percepatan pembelajaran dengan taraf keberhasilan tinggi.

d. Quantum learning sangat menekankan kebermaknaan dan kebermutuan proses pembelajaran.

e. Quantum learning memusatkan perhatian pada pembentukan keterampilan akademis, keterampilan (dalam) hidup, dan prestasi fisikal ataupun material.

\section{SIMPULAN}

Penerapan model pembelajaran Quantum learning dapat meningkatkan hasil belajar konsep Virus pada siswa kelas X MIA SMA Negeri Kartika XIII-1 Ambon. Hal tersebut dapat dibuktikan dengan tingkat keberhasilan siswa yang dilihat dari aspek kognitif, afektif, dan psikomotor. Hal ini sesuai dengan data analisis dan data presentase yang diperoleh pada tes awal adalah $65,31 \%$ sedangkan tes akhir presentase yang di hasilkan mencapai $79,68 \%$

\section{DAFTAR PUSTAKA}

Adityarini, Y., J. Waluyo, dan S. Aprilya. 2013. Penerapan Model Pembelajaran Quantum Learning dengan Media Flashcard Untuk Meningkatkan Motivasi dan Hasil Belajar Siswa Kelas X Di SMA Negeri 1 Purwoharjo - Banyuwangi Tahun Pelajaran 2011/2012 (Pada Pokok Bahasan Animalia). Jurnal Pancaran (2)2:189-199.

Depdiknas. (2008). Kurikulum Tingkat Satuan Pendidikan. Jakarta: Dikmenum - Depdiknas.

Deporter, B., dan Mike Hernacki. 2007. Quantum Learning Membiasakan
Belajar Nyaman dan Menyenangkan, Bandung: Kaifa.

Lufri. 2010. Strategi Pembelajaran Biologi Teori, Praktek, dan Penelitian. Padang: Negeri Padang University Press.

Mahmud. 2011. Metode Penelitian Pendidikan. Bandung: Pustaka Setia

Purwanto Ngalim. 2011. IImu Teoritis dan Praktis, Bandung: PT. Remaja Rosdakarya.

Safryadi, A., M. Ali S., dan C. Nurmaliah. 2013. Upaya Peningkatan Hasil Belajar Kognitif Melalui Model Problem Based Learning. Jurnal Biotik 1(2): 67-136

Saragih, A., dan S. Kristiani. 2007. The Effect of Quantum Learning on the Students' Achievement in Writing Argumentation. Jurnal Biotik 1(1): 3435.

Sardiman. 2005. Interaksi dan Motivasi Belajar Mengajar. Jakarta: Raja Grafindo Persada.

Sudjana 2010. Dasar-dasar Proses Belajar, Sinar Baru Bandung

Sukanti. 2010. Penilaian Portofolio dalam meningkatkan Hasil Belajar. Jurnal Pendidikan Akuntansi Indonesia, Vol. VIII No. 2. Hal 33-40. 